\title{
PENGEMBANGAN MODEL TUTOR BIMBINGAN KONSELING SEBAYA (PEER COUNSELING) UNTUK MENGATASI MASALAH MAHASISWA FAKULTAS ILMU PENDIDIKAN UNDIKSHA
}

\author{
Kadek Suranata \\ Jurusan Bimbingan Konseling, Fakultas IImu Pendidikan \\ Universitas Pendidikan Ganesha \\ Singaraja Bali, Indonesia \\ e-mail: sura@konselor.org
}

\begin{abstract}
Abstrak
Penelitian ini bertujuan untuk mengembangkan model tutor bimbingan konseling teman sebaya untuk membantu meminimalisasi masalah yang dialami mahasiswa di Fakultas IImu Pendidikan Undiksha Singaraja. Secara lebih rinci tujuan penelitian ini adalah: (1) mengidentifikasi masalah-masalah yang dialami mahasiswa FIP Undiksha, dan (2) mengetahui validasi teoretik rumusan model. Penelitian ini menggunakan pendekatan pengembangan (research \& develovement) yang terdiri dari tujuh langkah pokok yaitu, (1) research and information collecting. (2) pllaning. merumuskan rencana penggunaan hasil penelitian, sasaran atau pengguna hasil penelitian, dan deskripsi komponen-komponen hasil penelitian serta, (3) develop preliminary form of product yaitu menyusunan draf uji coba hasil penelitian di lapangan (4) preliminary field testing and product revition yaitu melakukan evaluasi hasil penelitian untuk mengetahui apakah hasil penelitian dapat dikembangkan atau tidak (5) main field test and product revision yaitu melakukan uji kembali hasil-hasil yang telah dicapai, (6) operational field test and product revision yaitu mengkaji apakah hasil penelitian benar-benar dapat digunakan oleh praktisi pendidikan sebagai pelaksana dan pengembang pendidikan (7) dessemination implementastion and institutionalization, implementasi hasil-hasil penelitian melalui proses desiminasi di lembaga. Populasi penelitian adalah mahasiswa di Fakultas IImu Pendidikan Undiksha yang ditentukan dengan teknik proposional cluster random sampling serta pakar bimbingan konseling. Untuk mengidentifikasi masalah- masalah mahasiswa menggunakan instrumen alat ungkap masalah (AUM) jenis PTSDL seri mahasiswa selanjutnya data dianalisis menggunakan program komputer analisis AUM PTSDL versi 2011. Analisis validasi teoretik melibatkan dua orang pakar bimbingan konseling, data validasi dianalisis menggunakan teknik Geregory. Hasil penelitian menunjukkan: (1) masalah yang paling dirasakan mahasiswa FIP Undiksha berdasarkan hasil analisis AUM PTSDL adalah terkait dengan penguasaan keterampilan belajar dengan skor mutu 47,2 atau pada kategori rendah sedangkan rata-rata masalah yang dialami pada aspek keterampilan belajar ini adalah 22,5 atau pada kategori sedang. (2) hasil validasi model menggunakan nilai $R$ sebesar 0,90 yang dapat bermakna bahwa model tutor bimbingan konseling teman sebaya layak dikembangkan lebih lanjut.
\end{abstract}

Kata-kata kunci: Tutor sebaya, Bimbingan konseling, masalah, mahasiswa.

\begin{abstract}
This study aims to develop a model of peer counseling to help minimize the problems experienced by students college at Ganesha University of Education (Undiksha) Singaraja. In more detail the objectives of this study were: (1) identify the problems experienced by students college, (2) formulate a draft model of peer counseling in college, and (3) determine the theoretical formulation of the model validation. This study uses a research \& develovement, consisting of seven basic steps, namely, 1) research and information
\end{abstract}


collecting, (2) planning, (3) developing preliminary from of product, (4) preliminary field testing and product revision, (5) main field test and product revision, (6) operational field test and product revision, and (7) dissemination implementation and institutionalization. The study population consisted of students college in Faculty of Education Undiksha and expert counseling in Undiksha. Sample of students college was determined by proportional cluster random sampling technique. To identify the problem students college is Used problem cheklist namely AUM PTSDL types. The data were analyzed using a computer program analyzes AUM PTSDL 2011 version. Analysis of theoretical validation involves two experts in counseling, validation data were analyzed using techniques Geregory. The results showed: (1) the perceived problems of students college is associated with the acquisition of learning skills with quality score of 47.2 or lower, while the category average problems experienced on the skills aspect of this study is 22,5 or the category of being. (2) the results of the model of peer counseling validation using the $R$ value of 0.90 , which means should be developed further.

Key words: peer, guidance counselling, issues students, college.

\section{PENDAHULUAN}

Proses belajar mengajar di Perguruan Tinggi merupakan interaksi antara dosen dengan mahasiswa. Dosen memfasilitasi mahasiswa dalam mencapai tujuan belajarnya dan mahasiswa melakukan proses pembelajaran guna mendapatkan prestasi yang memuaskan. Tidak dapat dipungkiri bahwa semua orang memiliki potensi untuk mengalami masalah dalam kehidupannya, dimanampun, kapanpun serta apapun profesinya. Begitu juga dengan mahasiswa yang menjalani aktifitas di perguruan tinggi sangat rentan mengalami masalah. Berbagai tuntutan tugas perkuliahan di kampus, serta tuntutan kehidupan di luar kampus sangat sering menjebak para mahasiswa untuk mengalami masalah, baik masalah dalam bidang belajar atau akademik maupun masalah dalam aspek pribadi, sosial dan juga karier atau non-akademik.. Dalam perjalanan mahasiswa menuntut ilmu tidak akan luput dari masalah yang dihadapi baik masalah akademik maupun non akademik. Masalahmasalah tersebut dapat mempengaruhi tidak tercapainya prestasi optimal mahasiswa, atau salah satu indikator yang dapat dilihat dialimnya masalah oleh mahasiswa adalah dengan pencapain Indek Prestasi (IP) yang rendah, atau dibawah rata-rata.

$$
\text { Perlu diiingat bahwa pada }
$$
hakekatnya permasalahan-permasalahan yang muncul dan dapat diamati sebenarnya adalah hanya sebagian kecil dari permasalahan yang ada, bagaikan gunung es di tengah lautan (Freud, Corey, 2009). Sehingga untuk mengungkap permasalahan yang dialami oleh mahasiswa diperlukan kajian yang lebih mendalam dari sekedar melihat capaian IP mahasiswa tersebut, sehingga dapat diketahui masalah yang lebih jelas serta faktor-faktor penyebabnya.

Laporan pelaksanaan program student support service yang disingkat 35 (sebuah program yang dilaksanakan di bawah unit bimbingan konseling atau UBK Undiksha yang bertujuan membantu mahasiswa yang mengalami permasalahan dalam menempuh studi) pada tahun 2011 menunjukkan hasil yang positif dengan bukti peningkatan indeks prestasi dari masingmasing mahasiswa yang telah dibantu melalui UBK tersebut (Laporan UBK, 2011). Namun dilain sisi, masih ditemukan beberapa kelemahan dari pelaksanaan program UBK tersebut, diantaranya: (1) bimbingan konseling oleh UBK yang terlaksana oleh tim 3S Undiksha belum mampu membantu semua mahasiswa di Undiksha karena jumlah Tim 3S hanya 6 orang, yakni satu orang di masing-masing fakultas, (2) pembimbingan akademik oleh dosen pembimbing akademik (PA) sifatnya sangat terbatas karena frekuensinya hanya dua kali dalam satu semester, waktu yang 
dapat disediakan oleh PA sangat terbatas karena dosen PA juga adalah tenaga pengajar, (3) kurangnya kesiapan dan kepercayaan mahasiswa untuk mengungkapkan masalahnya kepada Tim UBK dan juga dosen PA sehingga masalah yang dialami mahasiswa tersebut tidak dapat dibantu dengan baik.

Berdasarkan hal tersebut, diperlukan suatu upaya berupa penerapan program dan/atau suatu model bimbingan konseling yang mampu menjawab kelemahan-kelamahan pelaksanaan bimbingan konseling yang selama ini terlaksana di UBK dan juga yang telah diberikan oleh dosen PA masing-masing mahasiswa di Undiksha. Pelayanan Bimbingan Konseling dengan memanfaatkan mahasiswa sebagai tutor teman sebaya atau model peer counseling diprediksikan efektif untuk membantu mahasiswa menyelesaikan permasalahan yang mereka alami selama mengikuti pendidikan di kampus. Konseling tutor teman sebaya merupakan suatu cara bagi para mahasiswa belajar bagaimana memperhatikan dan membantu mahasiswa lain, serta menerapkannya dalam kehidupan sehari-hari. Konseling sebaya merupakan suatu bentuk pendidikan psikologis yang disengaja dan sistematik. Konseling sebaya memungkinkan mahasiswa untuk memiliki keterampilan-keterampilan mengimplementasikan guna kemandirian dan kemampuan mengontrol diri yang sangat bermakna bagi mahasiswa, karena para mahasiswa berdasarkan tingkat perkembangannya adalah individu-individu yang sedang menjalani usia remaja akhir (adolescence), hal tersebut dijelaskan juga menurut Santrock (2002: 206) menyebutkan remaja berasal dari istilah adolescence yang memiliki arti tumbuh untuk mencapai kematangan, baik mental, emosional, sosial, dan fisik. Pada masa ini individu ditandai dengan adanya perkembangan yang pesat pada individu dari segi fisik, psikis dan sosialnya, yang mana pada masa ini keterikatan terhadap teman sebaya sangat kuat. Keadaan seperti ini menjadikan mahasiswa memiliki kelompok tersendiri, mereka lebih memilih memecahkan masalahnya dengan teman sebayanya dari pada dengan orang lain, masalah yang sangat seriuspun mereka biasanya akan membahas dengan teman sebayanya. Kedekatan antara mereka dapat mejadi peluang untuk menfasilitasi layanan Bimbingan dan Konseling dalam mengatasi permasalahan yang dialaminya.

Bimbingan konseling teman sebaya (Peer Counseling) merupakan suatu cara bagi siswa/mahasiswa belajar bagaimana memperhatikan dan membantu siswa/mahsiswa lain, serta menerapkannya dalam kehidupan sehari-hari (Carr, 1981: 3). Sementara itu, Tindall dan Gray (1985 : 5) mendefinisikan konseling teman sebaya sebagai suatu ragam tingkah laku membantu secara interpersonal yang dilakukan oleh individu nonprofesional yang berusaha membantu orang lain. Menurut Tindall \& Gray, konseling teman sebaya mencakup hubungan membantu yang dilakukan secara individual (one-to-one helping relationship), kepemimpinan kelompok, kepemimpinan diskusi, pemberian pertimbangan, tutorial, dan semua aktivitas interpersonal manusia untuk membantu atau menolong.

Definisi lain menekankan konseling teman sebaya sebagai suatu metode, seperti dikemukakan Kan (1996 : 3) "Peer counseling is the use problem solving skills and active listening, to support people who are our peers". Meskipun demikian, Kan mengakui bahwa keberadaan konseling teman sebaya merupakan kombinasi dari dua aspek yaitu teknik dan pendekatan. Berbeda dengan Tindall dan Gray, Kan membedakan antara konseling teman sebaya dengan dukungan teman sebaya (peer support). Menurut Kan, peer support lebih bersifat umum (bantuan informal; saran umum dan nasehat diberikan oleh dan untuk teman sebaya); sementara peer counseling merupakan suatu metode yang terstruktur. Konseling sebaya merupakan suatu bentuk 
pendidikan psikologis yang disengaja dan sistematik. Konseling sebaya memungkinkan siswa untuk memiliki keterampilan-keterampilan guna mengimplementasikan pengalaman kemandirian dan kemampuan mengontrol diri yang sangat bermakna bagi remaja. Secara khusus konseling teman sebaya tidak memfokuskan pada evaluasi isi, namun lebih memfokuskan pada proses berfikir, proses-proses perasaan dan proses pengambilan keputusan. Dengan cara yang demikian, konseling sebaya memberikan kontribusi pada dimilikinya pengalaman yang kuat yang dibutuhkan oleh para remaja yaitu respect. (Carr, $1981: 4$ ).

Pada awalnya konseling teman sebaya muncul dengan konsep peer support yang dimulai pada tahun 1939 untuk membantu para penderita alkoholik (Carter, 2005 : 2). Dalam konsep tersebut diyakini bahwa individu yang pernah kecanduan alkohol dan memiliki pengalaman berhasil mengatasi kecanduan tersebut akan lebih efektif dalam membantu individu lain yang sedang mencoba mengatasi kecanduan alkohol. Dari tahun ke tahun konsep teman sebaya terus merambah ke sejumlah setting dan issue.

Istilah "konselor" sebaya kadang menimbulkan kekhawatiran bagi sementara orang karena khawatir berkonotasi dengan konselor professional. Oleh karena itu beberapa orang menyebut "konselor sebaya" dengan sebutan "fasilitator", atau "konselor yunior". Terlepas dari berbagai sebutan yang digunakan, yang lebih penting sebenarnya adalah bagaimana mahasiswa/siswa berhubungan satu sama lain, dan dengan cara bagaimana hubungan-hubungan itu dapat digunakan untuk meningkatkan perkembangan mereka.

Konseling teman sebaya dipandang penting karena sebagian besar remaja (siswa dan mahasiswa) lebih sering membicarakan masalah-masalah mereka dengan teman sebaya dibandingkan dengan orang tua, pembimbing, atau guru di sekolah. Untuk masalah yang dianggap sangat seriuspun mereka bicarakan dengan teman sebaya (sahabat). Kalaupun terdapat remaja yang akhirnya menceritakan masalah serius yang mereka alami kepada orang tua, pembimbing atau guru, biasanya karena sudah terpaksa (pembicaraan dan upaya pemecahan masalah bersama teman sebaya mengalami jalan buntu). Hal tersebut terjadi karena remaja memiliki ketertarikan dan komitmen serta ikatan terhadap teman sebaya yang sangat kuat. Remaja merasa bahwa orang dewasa tidak dapat memahami mereka dan mereka yakin bahwa hanya sesama merekalah remaja dapat saling memahami. Keadaan yang demikian sering menjadikan remaja sebagai suatu kelompok yang eksklusif. Fenomena ini muncul sebagai akibat dari berkembangnya karakteristik personal fable yang didorong oleh perkembangan kognitif dalam masa formal operations (Steinberg, 1993; Santrock, 2004). Keeratan, keterbukaan dan perasaan senasib di antara sesama remaja dapat menjadi peluang bagi upaya memfasilitasi perkembangan remaja. Pada sisi lain, beberapa karakteristik psikologis remaja (emosional, labil) juga merupakan tantangan bagi efektivitas layanan konseling teman sebaya.

Terdapat beberapa area dasar yang memiliki sumbangan penting terhadap perlunya dikembangkan konseling teman sebaya khususnya di perguruan tinggi (Carr, 1981: 5-12) :

Yang pertama, hanya sebagian kecil mahasiswa yang memanfaatkan dan bersedia berkonsultasi langsung dengan konselor. Para mahasiswa lebih sering menjadikan teman-teman mereka sebagai sumber yang diharapkan dapat membantu pemecahan masalah yang mereka hadapi. Para mahasiswa tetap menjadikan temanteman mereka sebagai sumber pertama dalam mempertimbangkan pengambilan keputusan pribadi, perencanaan karir, dan bagaimana melanjutkan pendidikan formal mereka,

Kedua, berbagai keterampilan yang terkait dengan pemberian bantuan yang 
efektif dapat dipelajari oleh orang awam sekalipun, termasuk oleh para-profesional dan mahasiswa di perguruan tinggi dapat dikuasai oleh para siswa SMP (Carr, 1981), para siswa SMA bahkan oleh para siswa Sekolah Dasar. Pelatihan konseling sebanya itu sendiri juga dapat merupakan suatu bentuk treatment bagi para "konselor" sebaya dalam membantu perkembangan psikologis mereka.

Ketiga, berbagai penelitian secara konsisten menunjukkan bahwa di kalangan remaja, kesepian atau kebutuhan akan teman merupakan salah satu di antara lima hal yang paling menjadi perhatian remaja. Hubungan pertemanan bagi remaja sering kali menjadi sumber terbesar bagi terpenuhinya rasa senang, dan juga dapat menjadi sumber frustrasi yang paling mendalam. Kenyataan ini menunjukkan bahwa teman memungkinkan untuk saling bantu satu sama lain dengan cara yang unik dan tidak dapat diduga oleh para orang tua dan para pendidik. Mahasiswa menjelaskan seorang teman sebagai orang yang mau mendengarkan, mau membantu, dan dapat berkomunikasi secara mendalam. Persahabatan ditandai dengan kesediaan untuk dapat saling bantu (dapat menjadi penolong) satu sama lain.

Keempat, dasar keempat penggunaan mahasiswa untuk membantu mahasiswa lainnya muncul dari penekanan pada usaha preventif dalam gerakan kesehatan mental dan penerapan konseling preventif (Carr, 1981) dalam setting sekolah. Program prevensi memiliki dua level tujuan yaitu: 1) kebutuhan untuk memperkuat (atau imunisasi) siswa dalam menghadapi pengaruh-pengaruh yang membahayakan (melalui pemberian keterampilan pemecahan masalah secara lebih efektif), dan 2) pada saat yang sama mengurangi insiden faktor-faktor destruktif secara psikologis yang terjadi dalam lingkungan misalnya dengan mengeliminasi lingkungan yang kurang mendukung.

Kelima, mahasiswa perlu memiliki kompetensi (menjadi kuat), perlu kecerdasan (bukan akademik, tetapi memahami suasana), pengambilan peran tanggung jawab (menjadi terhormat) dan harga diri (menjadi bermakna dan dapat dipahami). Para mahasiswa memahami bagaimana kuatnya kebutuhan-kebutuhan tersebut. Sebagian orang tua kurang memahami keadaan ini, sehingga remaja sering kali mencari sesama remaja yang memiliki perasaan sama, mencari teman yang mau mendengarkan, dan bukan untuk memecahkan atau tidak memecahkan problemnya, tetapi mencari orang yang mau menerima dan memahami dirinya.

Keenam, suatu issue kunci pada masa remaja adalah kemandirian (independence), tetapi adalah suatu hal yang penting bagi orang dewasa untuk memahami kemandirian dalam kaitannya dengan perspektif budaya teman sebaya. Sebagai contoh, Goleman (1980) telah menemukan bahwa bagi remaja laki-laki, independensi berarti kebebasan dari pengekangan atau pembatasanpembatasan tertentu. Sedangkan bagi remaja perempuan, independensi berarti suatu kebebasan internal, atau kesempatan untuk menjadi diri sendiri dan kesempatan untuk memiliki beberapa kemandirian yang berkaitan dengan perasaan-perasaan dan pikiran-pikiran seseorang.

Secara umum, penelitian-penelitian yang dilakukan tentang pengaruh tutor sebaya menunjukkan bahwa penggunaan teman sebaya (tutor sebaya) dapat memperbaiki prestasi dan harga diri siswasiswa lainnya. Beberapa siswa lebih senang belajar dari teman sebayanya. Berkaitan dengan itu, Suranata dan Madri Antari (2009) melalui penelitian mengenai peran personil sekolah dan Osis dalam pelayanan bimbingan konseling di SMU Kodya denpasar menemukan bahwa Osis memiliki peran penting dalam membantu siswa mengatasi masalah yang dialami. Peran Osis tersebut terlaksana melalui bimbingan konseling teman sebaya yang telah dibentuk oleh guru pembimbing di sekolah yang diteliti. 


\begin{abstract}
Konseling teman sebaya secara kuat menempatkan keterampilanketerampilan komunikasi untuk memfasilitasi eksplorasi diri dan pembuatan keputusan. "Konselor" sebaya bukanlah konselor profesional. "Konselor" sebaya adalah para mahasiswa yang memberikan bantuan kepada mahasiswa lain di bawah bimbingan konselor ahli. Dalam konseling sebaya, peran dan kehadiran konselor ahli tetap diperlukan. Pada hakekatnya peer counseling adalah counseling through peers

Berdasarkan hal tersebut di atas, maka penelitian ini bermaksud untuk mengembangkan model bimbingan konseling teman sebaya (peer counseling) untuk mengatasi masalah akademik dan non-akademik mahasiswa Universitas Pendidikan Ganesha. Secara lebih rinci penelitian ini bertujuan: (1) mengidentifikasi jenis masalah yang dialami mahasiswa Undiksha, (2) merumuskan prosedur dan sintaks model bimbingan konseling teman sebaya (peer counseling) untuk mengatasi masalah yang dihadapi mahasiswa Undiksha, (3) mengetahui validitas teoritik rancangan model bimbingan konseling teman sebaya (peer counseling) untuk mengatasi masalah yang dihadapi mahasiswa Undiksha.
\end{abstract}

\section{METODE}

Penelitian ini menggunakan pendekatan pengembangan (research and development atau $R \& D$ ) yang terdiri dari tujuh langkah pokok yaitu, (1) research and information collecting. (2) pllaning. merumuskan rencana penggunaan hasil penelitian, sasaran atau pengguna hasil penelitian, dan deskripsi komponenkomponen hasil penelitian serta, (3) develop preliminary form of product yaitu menyusunan draf uji coba hasil penelitian di lapangan (4) preliminary field testing and product revision yaitu melakukan evaluasi hasil penelitian untuk mengetahui apakah hasil penelitian dapat dikembangkan atau tidak (5) main field test and product revision yaitu melakukan uji kembali hasil-hasil yang telah dicapai, (6) operational field test and product revision yaitu mengkaji apakah hasil penelitian benar-benar dapat digunakan oleh praktisi pendidikan sebagai pelaksana dan pengembang pendidikan (7) dessemination implementastion and institutionalization, implementasi hasil-hasil penelitian melalui proses desiminasi di lembaga atau sekolah.

Populasi penelitian adalah para mahasiswa di Fakultas IImu Pendidikan Undiksha yang aktif pada tahun ajaran 2012 sebanyak 2676 orang dan pakar bimbingan konseling di Undiksha. Sampel penelitian dari mahasiswa ditentukan dengan teknik proporsional cluster random sampling. Berdasarkan penentuan sampel tersebut maka jumlah sampel mahasiswa yang akan dilibatkan sebagai sampel dalam identifikasi masalah melalui alat ungkap masalah (AUM) adalah sebesar 398.

Untuk mengidentifikasi masalahmasalah yang dialami mahasiswa digunakan instrumen alat ungkap masalah (AUM) PTSDL seri mahasiswa dan data dianalisis menggunakan program analisis AUM yang dikembangkan oleh Prayitno,dkk (2007).

Analisis validasi model teoretik dilakukan dengan uji pakar dan dianalisis dengan rumus Gregory.

\section{HASIL DAN PEMBAHASAN}

Identifikasi jenis masalah yang dialami mahasiswa dalam penelitian ini menggunakan instrumen berupa alat ungkap masalah (AUM) jenis PTSDL seri mahasiswa yang dikembangkan Pryitno dkk. Berdasarkan analisis dapat diketahui profil masalah yang dialami mahasiswa Fakultas ilmu pendidikan seperti pada tabel 1 berikut. 
Tabel 1 Hasil analisis AUM PTSDL Kelompok Mahasiswa FIP Undiksha

\begin{tabular}{|c|c|c|c|c|c|c|c|c|c|}
\hline & \multirow[b]{2}{*}{ BIDANG MASALAH } & \multicolumn{4}{|c|}{ S K O R } & \multicolumn{4}{|c|}{ MASALAH } \\
\hline & & $\begin{array}{c}\text { TER- } \\
\text { TINGG } \\
\text { I }\end{array}$ & $\begin{array}{c}\text { TER- } \\
\text { REND } \\
\text { AH }\end{array}$ & JML & $\begin{array}{c}\text { RATA2 } \\
\text { PER } \\
\text { MHS }\end{array}$ & $\begin{array}{c}\text { TER- } \\
\text { TINGG } \\
\text { I }\end{array}$ & $\begin{array}{c}\text { TER- } \\
\text { RENDA } \\
\mathbf{H}\end{array}$ & JML & $\begin{array}{c}\text { RATA } \\
2 \\
\text { PER } \\
\text { MHS }\end{array}$ \\
\hline 1 & $\begin{array}{l}\text { Prasyarat Penguasaan } \\
\text { Materi Pelajaran }\end{array}$ & 30 & 0 & 548 & 15.2 & 11 & 1 & 203 & 5.6 \\
\hline 2 & Keterampilan Belajar & 116 & 12 & 1698 & 47.2 & 40 & 2 & 810 & 22.5 \\
\hline 3 & Sarana Belajar & 26 & 4 & 513 & 14.3 & 9 & 1 & 157 & 4.4 \\
\hline 4 & Diri Pribadi & 46 & 5 & 898 & 24.9 & 13 & 1 & 253 & 7.0 \\
\hline 5 & $\begin{array}{l}\text { Lingkungan Belajar dan } \\
\text { Sosio-Emosional }\end{array}$ & 38 & 5 & 800 & 22.2 & 12 & 1 & 209 & 5.8 \\
\hline & Keseluruhan & 237 & 42 & 4457 & 123.8 & 71 & 9 & 1632 & 45.3 \\
\hline
\end{tabular}

Berdasarkan tabel 1 di atas dapat dilihat skor mutu belajar pada aspek penguasaan materi pelajaran tertinggi yang dicapai oleh mahasiswa adalah 30 sedangkan terendah adalah 0 dan rata-rata skor mutu penguasaan materi pelajaran mahasiswa adalah 15,2 ini termasuk pada kategori tinggi (Prayitno, dkk 2007). Selanjutnya jumlah masalah yang dialami pada prasyarat penguasaan materi ini adalah pada rata-rata 5,6 dapat dikategorikan rendah. Berdasarkan hasil ini dapat dinyatakan bahwa mahasiswa FIP Undiksha tidak mengalami permasahan pada aspek prasyarat penguasaan materi perkuliahan.

Selanjutnya pada aspek keterampilan belajar skor mutu yang tertinggi dicapai adalah 116 skor terendah adalah 12, rata-rata mutu belajar mahasiswa 47,2 atau pada kategori rendah. Selanjutnya rata-rata masalah yang dialami pada aspek keterampilan belajar ini adalah 22,5 atau pada kategori sedang. Berdasarkan hasil ini dapat diketahui bahwa mahasiswa mengalami masalah pada aspek keterampilan belajar.

Pada asepk sarana belajar skor mutu tertinggi yang dicapai adalah 26, terendah 4 , dan rata-rata skor mutu 14,3 atau berada pada kategori cukup. Selanjutnya rata-rata masalah yang dialami pada aspek ini adalah 4,4 pada kateori rendah.

Pada asepk diri pribadi skor mutu tertingi adalah 46 , skor terendah 4 dan ratarata adalah 29,4 pada kategori sedang. Dan rata-rata masalah yang dialami mahasiswa pada aspek diri pribadi adalah 7,0 pada kategori rendah.

Pada aspek lingkungan belajar dan lingkungan sosio-emosional nilai tertinggi adalah, 38, skor terendah 5 dan skor ratarata 22,2 pada kategori sedang. Rata-rata masalah yang dialami mahasiswa adalah 5,8 atau pada kategori rendah.

Berdasarkan uraian di atas dapat diketahui bahwa aspek yang menjadi permasalahan yang paling banyak dirasakan mahasiswa adalah pada keterampilan belajar. Artinya mahasiswa FIP Undiksha secara umum memerlukan upaya peningkatan keterampilan belajar yang lebih baik.

Secara lebih jelas gambaran skor mutu dan masalah yang dialami mahasiswa FIP Undiksha berdasarkan aspek prasyarat penguasaan materi, keterampilan belajar, sarana belajar, diri pribadi, dan lingkungan 
belajar sosio emosional dapat dilihat pada gambar 1 berikut.

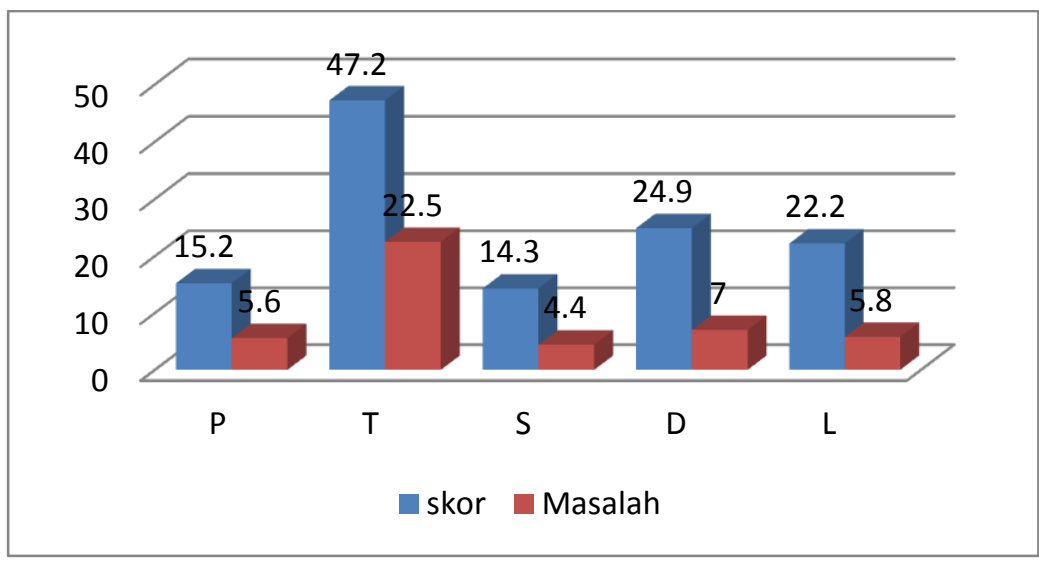

\section{Gambar 1 Grafik Rata-Rata Mutu Dan Masalah Aspek PTSDL Mahasiswa FIP Undiksha}

Rumusan model bimbingan konseling teman sebaya (peer counseling) di perguruan tinggi yang disusun terdiri dari dua bagian, bagian pertama membahas tentang konsep dan prosedur pelaksanaan bimbingan konseling teman sebaya di perguruan tinggi, bagian II membahas tentang keterampilan yang dilatihkan kepada para calon konselor/tutor sebaya. Analisis Geregory validasi model melalui judges dari dua orang pakar memperoleh nilai $R$ sebesar 0,90 yang dapat dimaknai bahwa model layak dikembangkan lebih lanjut.

Hasil identifikasi tentang masalah yang dialami mahasiswa menunjukkan bahwa masalah yang paling dirasakan oleh mahasiswa FIP Undiksha dari aspek PTSDL adalah mengenai penguasaan keterampilan belajar. Dalam arti mahasiswa memerlukan upaya untuk meningkatkan keterampilan belajarnya baik di ruangan kelas di kampus maupun di rumah. Berdasarkan hal tersebut maka rumusan model bimbingan konseling teman sebaya (peer counseling) yang disusun adalah dalam bentuk layanan bimbingan konseling kelompok dan juga individual yang dapat memfasilitasi mahasiswa mendapatkan sharing dengan teman sebaya yang terlatih (konselor sebaya/tutor sebaya bimbingan konseling) dalam upaya meningkatkan keterampilan belajarnya. Namun demikian permasalahan pada setiap manusia sifatnya dinamis dalam artian pada setiap waktu permasalahan tersebut dapat bergerak terus dari aspek satu ke asepk yang lainnya, terkait ha itu model tersebut juga tidak terbatas pada aspek peningkatan ketarampilan belajar saja, namun lebih luas dapat dimanfaatkan untuk membantu terfasilitasinya sharing antara mahasiswa terlatih atau konselor sebaya dengan mahasiswa lain yang memerlukan bantuan.

Rumusan model yang disusun pada penelitian ini belumlah fix model atau model akhir, karena pada tahap penelitian ini belum dilakukan uji coba secara emperik di lapangan, validasi yang dilakukan terbatas pada validasi secara teoretik oleh para pakar bimbingan konseling. Untuk pengembangan lebih lanjut diperlukan adanya uji coba secara emperik untuk mengetahui pengaruh model terhadap penurunan maslah-masalah yang dialami mahasiswa FIP Undiksha dan secara lebih luas kepada mahasiswa Undiksha.

\section{SIMPULAN DAN SARAN}

Berdasarkan uraian hasil penelitian di atas dapat disimpulkan beberapa hal sebagai berikut: (1) identifikasi masalah 
yang dialami oleh mahasiswa FIP Undiksha menggunakan alat ungkap masalah (AUM) dengan aspek (PTSDL) yakni; penguasaan materi pembelajaran, keterampilan belajar, sarana belajar, diri pribadi serta lingkungan belajar dan sosioemosional ditemukan bahwa masalah yang paling dirasakan oleh mahasiswa adalah pada keterampilan belajar, (2) model bimbingan konseling teman sebaya adalah salah satu upaya bantuan yang diberikan kepada mahsiswa melalui pemanfaatan mahasiswa terlatih sebagai tutor/konselor sebaya. Dalam pelaksanaanya tutor sebaya mendapatkan supervisi dari konselor ahli. Pelatihan terhadap para calon konselor/tutor sebaya meliputi penguasaan keterampilan dan tekhnik komunikasi atau wawancara konseling secara individual dan penguasaan prosedur memimpin kelompok dalam bimbingan konseling kelompok, (3) Validasi secara contents melalui uji pakar menunjukkan skor analisis Gregory sebesar sebesar 0,90 yang berarti dapat memenuhi syarat untuk dikembangkan lebih lanjut dengan menguji coba untuk mengetahui dampak faesibilitas model secara emperik.

Melalui hasil penelitian ini disarankan kepada peneliti selanjutnya yang tertarik mengkaji model bimbingan konseling teman sebaya (peer counseling) khususnya di perguruan tinggi untuk memanfaatkan hasil penelitian ini sebagai dasar beripikir dan selanjutnya melakukan pengujian model secara emperik melalui uji coba lapangan. Selanjutnya kepada Unit Bimbingan Konseling (UBK) Undiksha untuk dapat memanfaatkan rumusan model ini sebagai pedoman dalam mengembangkan model bantuan melalui pemanfaatan mahasiswa sebaya dalam menyelenggarakan student suport service kepada mahasiswa Undiksha. Ucapan terimakasih ditujukan kepada isntitusi Universitas Pendidikan Ganesha melalui lembaga Peneltian yang telah mendanai penelitian ini. selanjutnya kepada Unit Bimbingan Konseling (UBK) beserta tim student Suport Service UBK Undiksha yang telah memberikan bantuan dan informasi terkait data yang diperlukan dalam penelitian ini.

\section{DAFTAR PUSTAKA}

Corey, Gerald. 1999. Teori dan Praktek Konseling dan Psikoterapi. Bandung: Refika Aditama

Carr, R.A. 1981. Theory and Practice of Peer Counseling. Ottawa: Canada Employment and Immigration Commission

Carter, T. D. 2005. Peer Counseling: Roles, Functions, Boundaries. ILRU Program. Artikel Online. Tersedia: http://www.peercounseling.com. Diskases 25 Desember 2011

Daniel Goleman, alihbahasa T. Hermaya.1998. Emotional Intelligence. Jakarta: Gramedia Pustaka Utama.

Kan, P.V.1996. Peer Counseling in Explanation. Artikel Online. Tersedia: http://www.peercounseling.com. Diakses, 25 Desember 2011

Santrock, J.W. 2002. Life Span Development. Alih Bahasa: Ach. Chusairi \& Juda Damanik. Jakarta: Erlangga

Suranata,Kadek \& Madri Anatari. 2009. Peranan Personil sekolah dan OSIS dalam Pelayanan Bimbingan Konseling: Studi Pada SMU Kodya Denpasar. Laporan Penelitian DIPA Undiksha. Tidak Terbit.

Tindall, J.D. and Gray, H.D. 1985. Peer Counseling: In-Depth Look At Training Peer Helpers. Muncie: Accelerated Development Inc.

UBK. 2011. Laporan Pelaksanaan program 3S UBK tahun 2011. Tidak terbit

Pryitno, Dkk 2007 Alat ungkap Masalah (AUM) PTSDL Seri Mahasiswa. Proyek PGSM Ditjen Dikti Depdikbud. 